\title{
Estimating USLE Soil Erosion through GIS- based Decision Support System
}

\author{
Y. G. Her* - M. S. Kang ${ }^{* *},+$ S. W. Park ${ }^{* * *}$
}

\begin{abstract}
The objective of this study was to develop a GIS-based decision support system (GIS-USLE system) to estimate soil erosion and evaluate its effect on concentrated upland plots in Godang district, Korea. This system was developed for the ArcView environment using AVENUE script. Three modules were used in the GIS-USLE system, namely pre-processing, the USLE factors calculator module, and post-processing. This system benefits from a user friendly environment that allows users with limited computer knowledge to use it. This system was applied to 1,285 individual upland plots ranging from 0.005 to 1.347 ha in size with an average slope steepness of $14 \%$. The rainfall distributions were estimated using the three methods, namely Mononobe and Yen-Chow with Triangle and with Trapezoid type, and then used to calculate the rainfall erosivity factor. The soil erosion amounts from the 1,285 individual plots in the study area by 2 year return period with a $24 \mathrm{~h}$ maximum rainfall amount of $154.6 \mathrm{~mm}$ were estimated at $5 \mathrm{tons} / \mathrm{ha}$ on average. Slope appeared to be the most important factor affecting soil erosion estimation, as expected. The prototype model was applied to the project area, and the results appeared to support the practical applications. By examining many fields simultaneously, this system can easily provide fast estimation of soil erosion and thus reveal the spatial pattern of erosion from fields in a region. This study will help estimate and evaluate soil erosion in concentrated upland districts and identify the best management practices.
\end{abstract}

Keywords : Soil erosion, Upland, Geographical information system, Decision support system, Graphic user interface

* Dept. of Biological Systems Engineering, Virginia Polytechnic Institute and State Univ., Blacksburg, VA 24061

** Corresponing author, Dept. of Biosystems Eng, Auburn Univ. Auburn, AL 36832

$* * *$ Dept. of Agricultural Engineering, Seoul National Univ. Seoul, the Republic of Korea

$\dagger$ Corresponding author. Tel.: $+1-334-844-3549$

Fax: +1-334-844-3530

E-mail address: kangmoo@auburn.edu

\section{Introduction}

Soil erosion from agricultural land results in the loss of nutrients and production capability, as well as adversely affecting water quality as nonpoint source pollutants. In order to reduce soil erosion it is necessary to be able to identify excessive soil loss areas and estimate the soil loss using an erosion model. One of the most 
widely adopted soil erosion models is the Universal Soil Loss Equation (USLE), which is often used by planners to predict the impact of land use on soil erosion. Although originally developed to predict annual soil erosion over long time periods, it has been modified to estimate monthly and single-storm erosion (Cooley, 1980 ; Foster \& Williams, 1983 ; Kim 1999). For example, the 'National Cooperative Highway Research Program Synthesis of Highway Practice 70, DESIGN OF SEDIMENTATION BASINS' (Transportation Research Board, 1980) uses a method to calculate the rainfall factor $\mathrm{R}$ for $\mathrm{a}$ single storm that is based on the definition of an $R$ factor: "the number of erosion-index units in a normal year's rain. The erosion index is a measure of the erosive force of specific rainfall."

Improvements to the USLE based on more recent data, as well as a new evaluation of the original USLE data base, have resulted in a modification known as the Rivised Universal Soil Loss Equation (RUSLE) (Renard et al., 1993). RUSLE, in addition to incorporating new parameters, is available in computerized format. Although the algorithms with which to estimate RUSLE factors are more extensive, the regression form of the factors that are used in RUSLE remain the same as those in USLE.

Due to advances in computer and information technology, recent research has been directed towards the automation of erosion prediction by integrating models with Geographical Information System (GIS) to save time and field work. GIS database can be readily accessed for correcting or updating data, while the manual approach was not as flexible. Data of various types are collected in the form of layers, typically soils, topo- graphy, land use and so on. Many GIS and erosion linkage models utilize an approach based on studying the problem at a watershed scale with a grid format. Some researchers have examined the performance of models designed to estimate soil erosion from a watershed using both GIS and USLE (Yitayew et al, 1999; Ouyang and Bartholic, 2001). They concluded that combining the GIS application with USLE can provide easy and quick calculation tools with which to estimate soil erosion. Even though existing models such as the Water Erosion Prediction Project (WEPP) can provide good estimates of soil erosion from a single field, a great deal of additional effort and time is needed to extend this to cover many fields. In order to alleviate this problem, a comprehensive soil erosion estimation system that can handle many fields simultaneously needs to be developed.

The objectives of this study are to develop a GIS-based decision support system to estimate soil erosion and to evaluate its usefulness on the many of plot scale. This study will focus on estimating of an erosivity factor that is based on the theoretical rainfall time distribution, an assessment of GIS based soil erosion factors in USLE, and estimates of soil erosion for a group of individual fields on a hillslope at the same time.

\section{Materials and Methods}

\section{Study Site}

Godang district in JeollaNamdo province in Korea, which has 1,285 individual upland plots totaling with about 300 ha in size, was selected as the study site (Fig. 1). Approximately two 


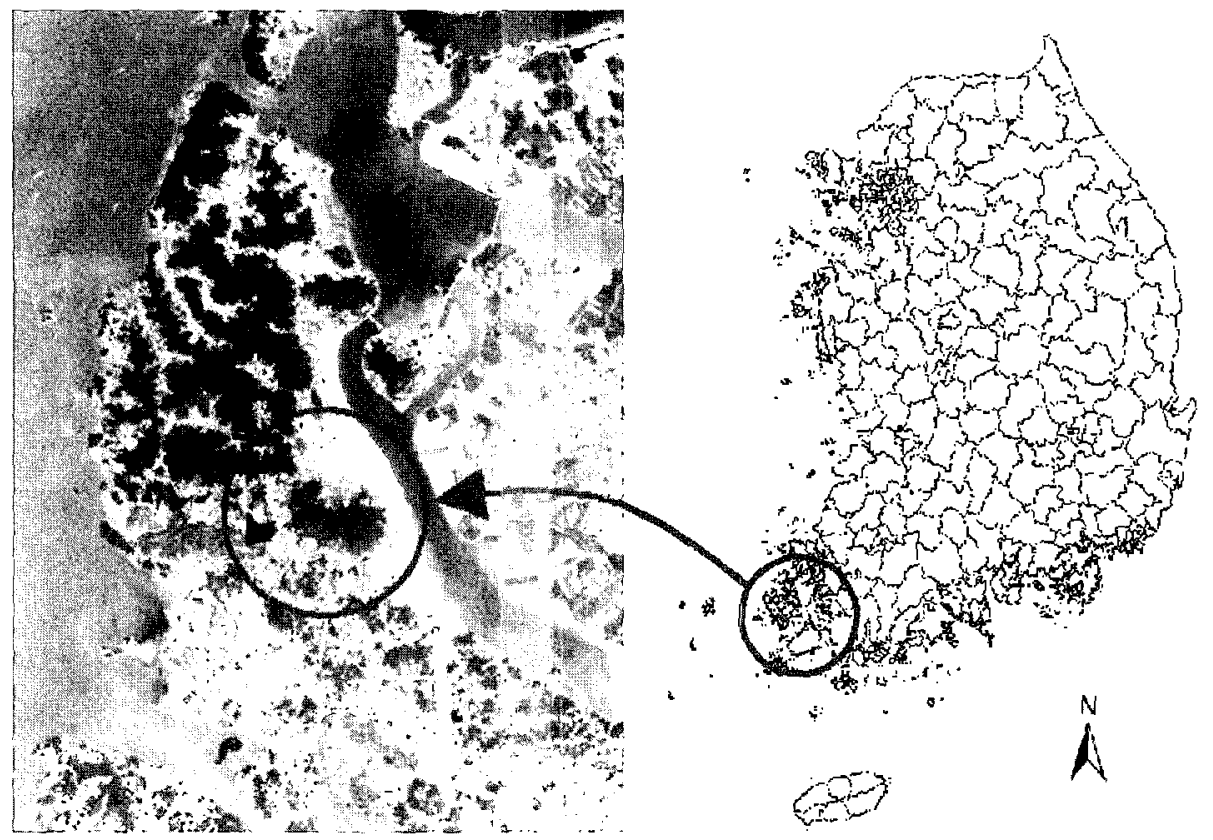

Fig. 1 Location of Godang district selected for this case study

thirds of the upland plots have slopes exceeding 5 degrees. The soil type in the study site was mostly clay loam with moderate runoff potential. Onions, peppers, cabbages, and dry-field rice are cultivated on these upland plots. The average plot area was 0.233 ha, with individual plots ranging from 0.005 ha to 1.347 ha.

\section{GIS-USLE system}

The GIS-USLE system based on a singlestorm and plot scale model was developed to estimate soil erosion for individual fields on a hillslope using the USLE integrated in a GIS environment (Fig. 2). This system, which has a very user friendly environment, allows even users with limited computer knowledge to use it successfully. For example, for convenience, the graphical user interface (GUI) provides an in- strument operating system that has pull-down menus. Furthermore, it aids the user's decision making process regarding the estimation of soil erosion by displaying the operational results of the programs in the form of graphical images, tables, and charts.

This system was developed in an ArcView environment using the AVENUE programming script. There are three main modules in the GIS-USLE system: pre-processing, the USLE factors calculator module, and post-processing (Fig. 3). The pre-processing module in the system creates a digital elevation model (DEM) that shows the boundaries of each field from topographical layers. The module also provides each field's DEM so that the user can calculate the slope and slope length of the fields. The USLE factor calculator extracts the input parameters and calculates the factors for USLE from 


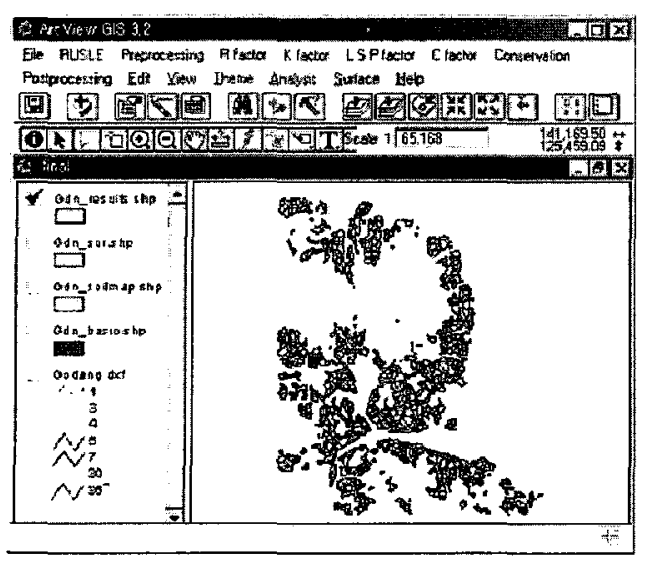

Fig. 2 Main screen of the GIS-USLE system

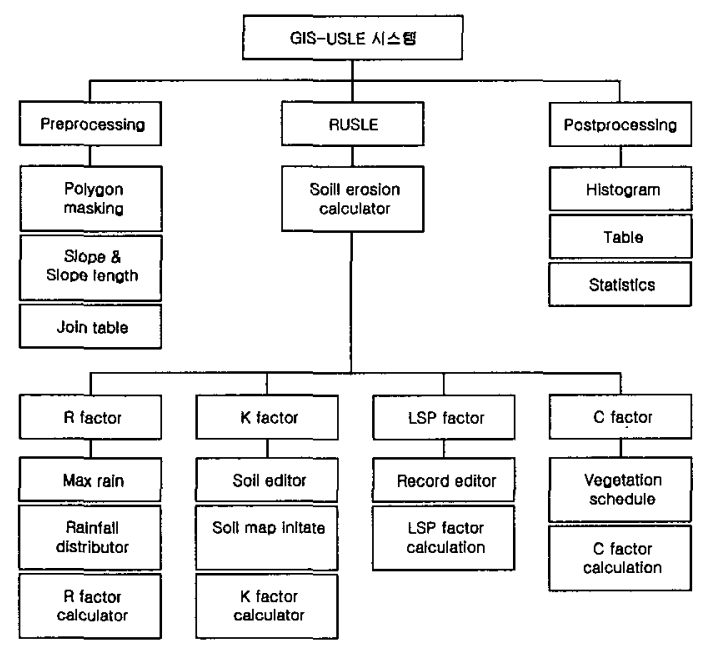

Fig. 3 Overall schematic of the system

Table 2 Input GIS data for the system.

\begin{tabular}{|c|c|c|c|c|c|}
\hline Map & Layer & Type & Contents & Scale & Remarks \\
\hline \multirow{7}{*}{$\begin{array}{l}\text { Topogra- } \\
\text { phical map }\end{array}$} & \multicolumn{2}{|c|}{ contour line } & altitude & \multirow{7}{*}{$1: 5,000$} & \multirow{7}{*}{ NGIS } \\
\hline & \multicolumn{2}{|c|}{ altitude point } & altitude & & \\
\hline & river & line & boundary & & \\
\hline & road & line & boundary & & \\
\hline & channe & line & boundary & & \\
\hline & $\begin{array}{l}\text { land } \\
\text { register }\end{array}$ & $\begin{array}{l}\text { line } \\
\text { polygon }\end{array}$ & boundary & & \\
\hline & district & line & boundary & & \\
\hline
\end{tabular}

Soil map soil polygon boundary 1:25,000 RDA the GIS data layers. This module consists of four sub-modules, namely $\mathrm{R}, \mathrm{K}$, LSP, and $\mathrm{C}$ factor modules. The R Factor Module calculates the rainfall erosibility factor with the TRB NCHRP method using either a real or an ideal rainfall distribution such as the Yen-Chow and Mononobe models. The $\mathrm{K}$ factor module calculates the soil erodibility factor for each field based on soil map and field feature layer. The LSP factor module is also used to calculate the slope length, slope steepness and erosion control practice factor. Using the topographical map layer and DEM from the pre-processing module, the slope length and steepness factor are then calculated. The erosion control practice factor module takes account of the erosion control practices selected by the user based on the GUI and the slope steepness of each field (Table 2). The $\mathrm{C}$ factor module calculates the average crop management factor for the whole study site during a single storm event.

The rainfall erosivity factor value requires the on-site rain gage data to be converted to an energy intensity value, which represents the total storm kinetic energy (E) times the maximum $30 \mathrm{~min}$ intensity $\left(\mathrm{I}_{30}\right)$. In the case of an ungauged region, the GIS-USLE system provides an ideal rainfall distribution with 6 minute time intervals for calculations of soil loss by two Yen-Chow methods, namely the triangle and trapezoid types, and the Mononobe method. The rainfall erosivity factor varies according to the rainfall distribution so that the value of the rainfall erosivity can vary according to the rainfall distribution.

The soil erodibility factor is related to the integrated effect of rainfall, runoff and infiltration 
on soil loss. The analytical relationship for the soil erodibility monograph (Wischmeier et al., 1971) can be used to compute an erodibility factor from the soil characteristics found in the digital soil maps $(1: 25,000)$. Each field's average soil erodibility factor is extracted from an intersecting and dissolving process for the field features and soil features by GIS-USLE (Fig. 4).

Slope steepness and length are derived by a DEM with a resolution of $1 \mathrm{~m}$ by $1 \mathrm{~m}$ using the maximum and minimum elevations and the straight line between the two elevation points of each field in GIS-USLE (Fig. 5). The length of the straight line is assumed to be the slope length and the slope of the line is assumed to be the slope steepness of each field. The DEM is computed based on the $5 \mathrm{~m}$ contours and interpolated linearly (Fig. 5).

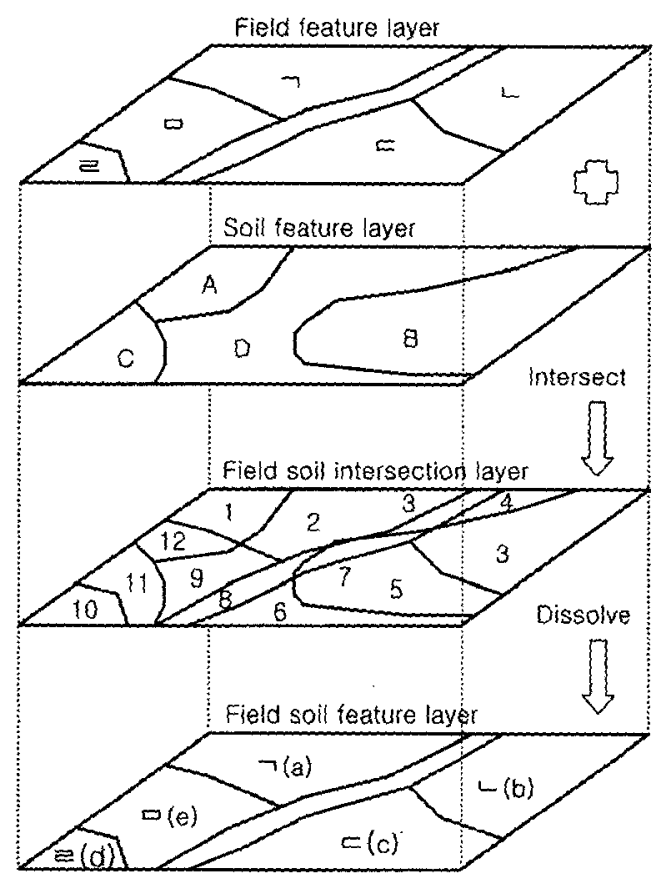

Fig. $4 \mathrm{~K}$ factor determination by GIS-USLE.

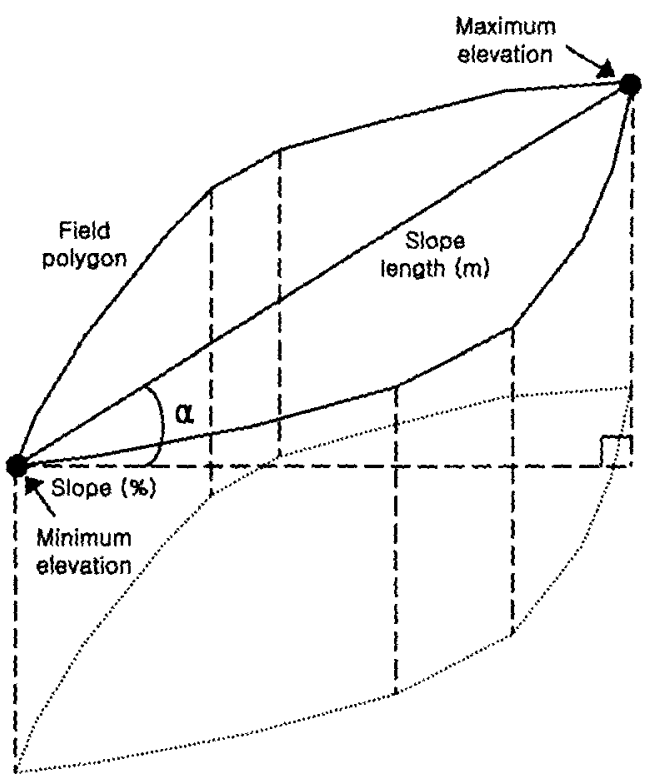

Fig. 5 Slope and slope length of individual fields.

\section{Results and Discussion}

\section{Raintall Erosivity}

A comparison of the storm erosivity factors calculated from the observed and simulated storm events is shown in Fig. 6 and Table 3. For the rainfall distribution, storm records with a rainfall depth of $15 \mathrm{~mm}$ as above for the period from 1999 to 2000 were obtained from the Suwon Weather Station. As shown in Fig. 6, the coefficient of determination $\left(R^{2}\right)$ values of the rainfall erosivity factor for the selected models were greater than 0.92 in every case.

The rainfall distributions calculated using three methods, namely the Mononobe method and the Yen-Chow method with both Triangle and Trapezoid and then used to determine the rainfall erosivity factor. The parameter values for the Yen-Chow model were obtained from KICT 
(2000). The rainfall erosivity factor estimated by the Mononobe method was generally higher than the observed values while the Yen-Chow methods both underestimated it. Also, the former suitably represented a high peak of the rainfall and the latter greatly underestimated (Table 3 ). The Mononobe method was therefore selected for the ideal rainfall distribution in this study. For the study area, the value of the rainfall erosivity factor calculated by the Mononobe method for a

Table 3 Comparison of the storm erosivity factor according to the rainfall distribution models for 26 storm events.

\begin{tabular}{|c|c|c|c|c|c|c|c|c|c|c|}
\hline \multicolumn{4}{|c|}{ Storm } & \multicolumn{4}{|c|}{$\begin{array}{l}\text { Storm erosivity factor } \\
\left(10^{7} \mathrm{~J} / \mathrm{ha} \cdot \mathrm{mm} / \mathrm{h}\right)\end{array}$} & \multicolumn{3}{|c|}{ Relative error $(\%)$} \\
\hline No. & $\begin{array}{c}\text { Amount } \\
(\mathrm{mm})\end{array}$ & $\begin{array}{c}\text { Duration } \\
(\mathrm{h})^{\circ}\end{array}$ & Date & Triangle & Trapezoid & Mono. & Observed & Triangle & Trapezoid & Mono. \\
\hline 1 & 16.20 & 14.8 & $99 / 09 / 18$ & 0.47 & 0.40 & 2.56 & 1.28 & & & 100.00 \\
\hline 2 & 18.40 & 10.1 & $99 / 10 / 02$ & 1.00 & 0.76 & 4.20 & 1.98 & & & 112.12 \\
\hline 3 & 20.20 & 5.7 & $99 / 10 / 01$ & 2.42 & 1.91 & 7.01 & 3.03 & & & 131.35 \\
\hline 4 & 21.60 & 10.4 & $99 / 09 / 09$ & 1.85 & 1.51 & 5.95 & 3.48 & & & 70.98 \\
\hline 5 & 23.40 & 22.9 & $00 / 05 / 26$ & 0.61 & 0.49 & 4.59 & 1.05 & & & 337.14 \\
\hline 6 & 28.60 & 11.5 & $99 / 06 / 23$ & 2.28 & 1.75 & 10.47 & 3.70 & & & 182.97 \\
\hline 7 & 29.40 & 11.1 & $00 / 08 / 31$ & 2.54 & 1.95 & 11.30 & 4.22 & & & 167.77 \\
\hline 8 & 29.60 & 10.6 & $99 / 10 / 10$ & 2.73 & 2.12 & 11.75 & 4.94 & & & 137.85 \\
\hline 9 & 36.00 & 14.0 & $00 / 09 / 14$ & 3.00 & 2.29 & 15.70 & 3.72 & & & 322.04 \\
\hline 10 & 43.80 & 14.9 & $00 / 08 / 23$ & 4.31 & 3.29 & 23.47 & 6.33 & & & 270.77 \\
\hline 11 & 44.60 & 20.6 & $00 / 06 / 26$ & 3.03 & 2.30 & 20.51 & 11.41 & & & 79.75 \\
\hline 12 & 45.90 & 23.1 & $99 / 09 / 23$ & 2.80 & 2.12 & 20.56 & 7.37 & & & 178.97 \\
\hline 13 & 47.60 & 18.3 & $99 / 05 / 03$ & 4.04 & 3.09 & 25.24 & 8.41 & & & 200.12 \\
\hline 14 & 49.20 & 5.2 & $99 / 07 / 09$ & 19.10 & 15,33 & 51.11 & 35.44 & & & 44.22 \\
\hline 15 & 49.20 & 6.1 & $99 / 09 / 05$ & 16.26 & 12.70 & 46.99 & 16.28 & & & 188.64 \\
\hline 16 & 49.60 & 8.5 & $99 / 08 / 01$ & 11.04 & 8.57 & 40.87 & 13.15 & & & 210.80 \\
\hline 17 & 52.60 & 7.4 & $00 / 06 / 29$ & 14.76 & 11.49 & 49.94 & 71.12 & & & -29.78 \\
\hline 18 & 52.60 & 4.1 & $00 / 08 / 04$ & 29.73 & 23.79 & 65.39 & 38.16 & & & 71.36 \\
\hline 19 & 63.20 & 1.8 & $00 / 06 / 10$ & 107.24 & 86.14 & 139.96 & 131.05 & & & 6.80 \\
\hline 20 & 66.00 & 14.1 & $00 / 08 / 24$ & 11.50 & 8.74 & 59.10 & 16.04 & & & 268.45 \\
\hline 21 & 84.00 & 16.4 & $00 / 08 / 20$ & 16.22 & 12.46 & 93.17 & 36.92 & & & 152.36 \\
\hline 22 & 107.40 & 27.2 & $00 / 08 / 27$ & 15.25 & 11.58 & 123.21 & 44.43 & & & 177.31 \\
\hline 23 & 148.80 & 40.3 & $00 / 09 / 15$ & 19.59 & 14.84 & 205.49 & 43.18 & & & 375.89 \\
\hline 24 & 191.80 & 22.1 & $99 / 08 / 02$ & 70.02 & 53.21 & 482.25 & 164.44 & & & 193.27 \\
\hline 25 & 277.60 & 47.1 & $99 / 09 / 19$ & 64.23 & 48.54 & 740.94 & 140.23 & & & 428.37 \\
\hline 26 & 303.60 & 13.2 & $00 / 07 / 22$ & 341.51 & 262.70 & $1,661.33$ & 745.65 & & & 122.80 \\
\hline \multicolumn{4}{|c|}{ RMSE } & 84.15 & 100.57 & 227.21 & - & - & - & - \\
\hline
\end{tabular}


2-year return period with a 24-h maximum rainfall amount of $154.6 \mathrm{~mm}$ was $290.4510^{7} \mathrm{~J} / \mathrm{h}$ $\mathrm{a} \cdot \mathrm{mm} / \mathrm{h}$.

The observed and simulated storms had the same rainfall amount and rainfall duration, but different time distributions (Fig. 7). Consequently, the observed and the simulated storms had different rainfall erosivity factors because then rainfall distributions were different. The results also show that the values of the rainfall erosivity factors calculated from storms with different storm duration but the same rainfall amount, were different. For example, in the case of storms No. 14 and 15, the storm amount was the same, at $49.20 \mathrm{~mm}$, but the rainfall duration was different. In this case, the values of the rainfall

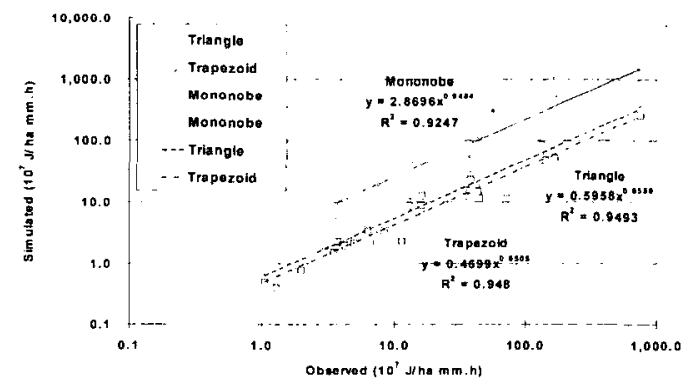

Fig. 6 Relationship between the observed and simulated storm erosivity factor according to the rainfall distribution models with Suwon rainfall data

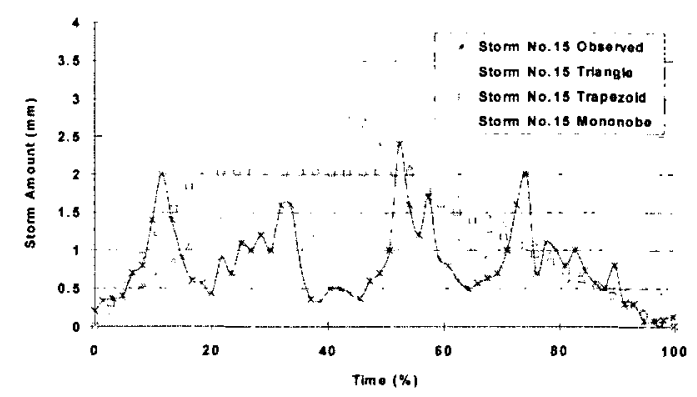

Fig. 7 Comparison of storm No. 15 and the ideal rainfall time distribution erosivity factors was also different. The same applies for storms No. 17 and 18. The effects of rainfall distribution and duration are reflected in the maximum 30 min intensity $\left(I_{30}\right)$ of the total storm kinetic energy (E).

\section{Soil Erodibility}

According to the soil map of the Godang region, the soil texture is composed of sandy clay loam and sandy clay. The permeability class classified by Soil Conservation Service National Soils Handbook (SCS, 1983) is class 5. The average value of the soil erodibility for all the study fields calculated using this system was 0.236 tons/ ha/ $\mathrm{R}$, ranging from 0.056 to 0.461 tons $/$ ha/ $R$. The values of the soil erodibility factor were estimated based on textual information for a fine sandy loam, loamy very fine sand, and sandy loam. (SCS, 1978).

\section{Slope Steepness and Length}

The topographical characteristics for each field derived from GIS-USLE included the area, slope length, and steepness, which were used to calculate the slope length and steepness factor for USLE (Table 4). The average values of the slope length, slope steepness, L factor and S factor for all the plots were $53.95 \mathrm{~m}, 14.04 \%$, 1,49 and 2.20 , respectively.

\section{Crop Management}

The crop management factors in USLE change with land use cover, resulting in varying erosion rates over the course of a season. However, 
Table 4 Topographical characteristics for the upland plots (1,285 fields) in the study area.

\begin{tabular}{lrrrrrr} 
Item & Area $\left(\mathrm{m}^{2}\right)$ & Perimeter $(\mathrm{m})$ & $\begin{array}{c}\text { Slope length } \\
(\mathrm{m})\end{array}$ & $\begin{array}{c}\text { Slope steepness } \\
(\%)\end{array}$ & L factor & S factor \\
\hline Average & 2.330 .0 & 204.6 & 53.95 & 14.04 & 1.49 & 2.20 \\
Min. & 53.0 & 46.7 & 3.61 & 0.84 & 0.40 & 0.11 \\
Max. & 13.472 .6 & 599.3 & 195.35 & 29.81 & 2.97 & 6.71 \\
St. Dev. & 1.846 .8 & 86.1 & 28.87 & 6.50 & 0.41 & 1.53 \\
Total & $299 \times 10^{4}$ & - & - & - & - & - \\
\hline
\end{tabular}

GIS-USLE cannot account for these seasonal effects because as a single storm based model, it assumes that the crop management factor values remain constant during each storm event. Also it uses an average crop management factor value for the cultivated crops during the storm event from user input supplied by GUI. Assuming the storm event occurs in late June, the average crop management factor value for the Godang region is 0.030 (Kim, 1995; Cho, 1998; and Yang, 1999).

\section{Support Practice}

GIS-USLE provides the option of support practice selection by the user from GUI and calculates the support practice factor value by taking into account the slope steepness of each plot. Assuming the support practice is contouring, the average value of the support practice will take a value of 0.747 according to the Rural Development Administration, Republic of Korea (RDA).

\section{Soil Erosion}

Using the results of the USLE factors subtracted from the previous steps, GIS-USLE calculates the soil erosion amount from each plot over the entire study area for an individual storm. From the 1,285 individual plots, with a total area of 299.4ha, GIS-USLE estimates the average soil erosion at 5tons/ha for rainfall of $154.6 \mathrm{~mm}$, which is the higher probability rainfall amount recorded by the Mokpo Weather Station at 24hours duration and 2-year recurrence interval.

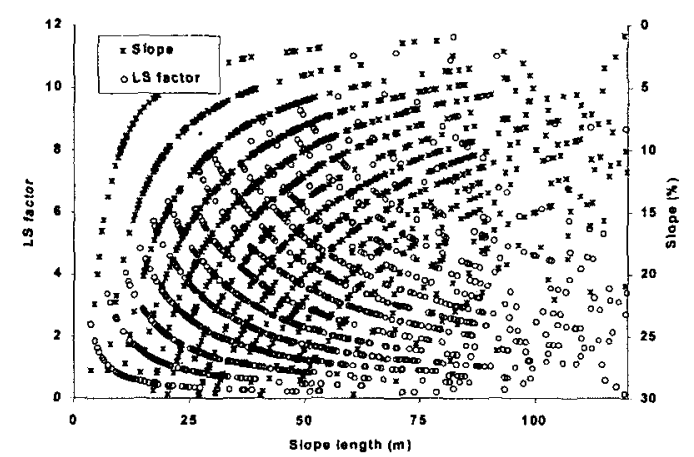

Fig. 8 Topographical factors according to the slope and slope length

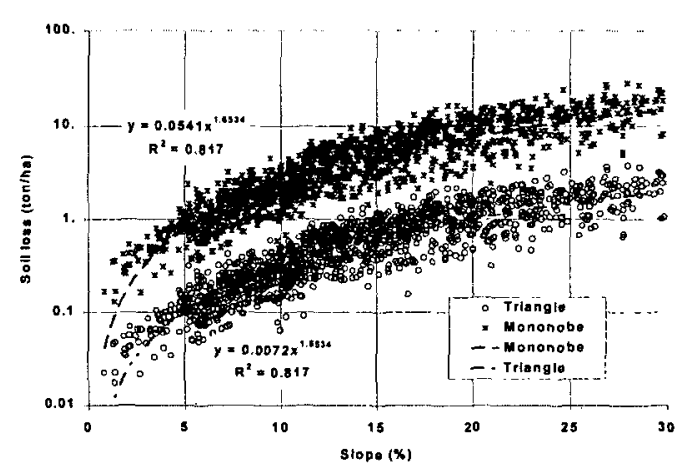

Fig. 9 Relationship between soil erosion and slope 
Examining the relationships between the topographic factors, slopes, and slope lengths for individual plots reveals that soil erosion has a strong relationship with the slope of each field. Fig. 8 depicts how the longer the slope length is, the shallower the slope of each plot becomes and Fig. 9 illustrates the adhesion and nonlinear relationship between soil erosion and slope.

The results also show that $35 \%$ of the plots, 491 plots, in the whole study area produce $70 \%$ of the total soil erosion. The average soil erosion from these plots which have the excessive soil erosion is estimated at about 10 tons/ha, which is twice the overall average for the same rainfall amount.

\section{Application}

Sediment yield measurements from an experimental upland plot at Seoul National University by Kim (1989) were used to verify the GIS-USLE performance. The plot has an area of 0.63 ha, a slope length of $125.4 \mathrm{~m}$, and a $4.83 \%$ average slope and its soil is composed of WonGog and GoPyung series. Also, corn was cultivated and grasses were grown on the field at the time of measurement. The erosivity factors for a series of storm events were calculated by
GIS-USLE's R factor module and the results are compared with those of Kim (1989) and Cho (1998) in Table 5.

The erosivity factors simulated from the Triangle model are much less than those calculated by either Kim (1989) and Cho (1998) because this model tends to underestimate the 30 minute maximum rainfall intensity. In the Mononobe case, the simulated factor could be either less or greater than their calculated values, and in both cases the simulated erosivity factors followed the variation of the rainfall amount. Thus, Mononobe should be considered a more appropriate rainfall time distribution method for use in estimating the erosivity factor for the system.



Fig. 10 Comparison of the simulated and observed soil erosion for several storms.

Table 5 Comparison of the simulated, Kim (1989) and Cho (1998) erosivity factors

\begin{tabular}{ccccccc}
\hline \multirow{2}{*}{$\begin{array}{c}\text { Storm event } \\
\text { date }\end{array}$} & $\begin{array}{c}\text { Storm amount } \\
(\mathrm{mm})\end{array}$ & \multirow{2}{*}{$\begin{array}{c}\text { Storm duration } \\
(\mathrm{h})\end{array}$} & \multicolumn{4}{c}{ Storm drosivity factor $(\mathrm{m} \cdot$ ton/ha) } \\
\cline { 4 - 7 } & 71.2 & 14 & 13.7 & 70.3 & 15.4 & 44.2 \\
\hline $12 / 07 / 88$ & 40.0 & 21 & 2.4 & 16.3 & 28.1 & 42.5 \\
$13 / 07 / 88$ & 29.3 & 24 & 1.0 & 7.6 & 12.0 & 6.0 \\
$14 / 07 / 88$ & 51.3 & 10 & 9.9 & 40.7 & 26.1 & 34.0 \\
$15 / 07 / 88$ & 191.8 & 69 & 27.0 & 134.9 & 81.6 & 126.7 \\
\hline Sum & & & & & &
\end{tabular}


Estimating USLE Soil Erosion through GIS-based Decision Support System

Table 6 Comparison of the soil loss between the simulated and the observed soil erosion

\begin{tabular}{|c|c|c|c|c|c|}
\hline \multirow{2}{*}{$\begin{array}{c}\text { Storm } \\
\text { event date }\end{array}$} & \multicolumn{3}{|c|}{ Soil loss (kg/ha) } & \multicolumn{2}{|c|}{ Relative bias (kg/ha) } \\
\hline & Triangle & Mononobe & Observed & Triangle & Mononobe \\
\hline $12 / 07 / 88$ & 32.8 & 168.3 & 4.4 & 6.455 & 37.250 \\
\hline $13 / 07 / 88$ & 5.7 & 39.0 & 60.2 & (-) 0.905 & (-) 0.352 \\
\hline $14 / 07 / 88$ & 2.4 & 18.2 & 29.0 & (-) 0.917 & (-) 0.372 \\
\hline $15 / 07 / 88$ & 23.7 & 97.4 & 83.3 & (-) 0.715 & 0.169 \\
\hline Sum & 64.6 & 322.9 & 176.9 & (-) 0.635 & 0.825 \\
\hline
\end{tabular}

Table 7 The observed runoff and peak discharge by storm events

\begin{tabular}{cccc}
\hline $\begin{array}{c}\text { Storm } \\
\text { events }\end{array}$ & $\begin{array}{c}\text { Rainfall } \\
(\mathrm{mm})\end{array}$ & $\begin{array}{c}\text { Runoff } \\
(\mathrm{mm})\end{array}$ & $\begin{array}{c}\text { Peak } \\
\text { discharge } \\
(\mathrm{mm} / \mathrm{h})\end{array}$ \\
\hline $12 / 07 / 88$ & 71.2 & 9.34 & 7.43 \\
$13 / 07 / 88$ & 40.0 & 29.47 & 25.34 \\
$14 / 07 / 88$ & 29.3 & 15.09 & 5.79 \\
$15 / 07 / 88$ & 51.3 & 33.29 & 20.21 \\
\hline
\end{tabular}

Using the corresponding rainfall amounts, the system estimated soil erosion for the plot to be $322.9 \mathrm{~kg} / \mathrm{ha}$ from the Mononobe method. These estimates are $183 \%$ of those measured by Kim (1989) (Table 6 and Fig. 10).

Because GIS-USLE cannot take into account infiltration processes due to its use of USLE, it is limited to representing soil erosion estimates that are proportional to the rainfall amounts. However, soil particles are detached not only due to rainfall energy but also flow, and further research using a modified USLE (MUSLE) application with GIS for consideration of flow are needed. There is a big difference between the observed and simulated soil erosions on the first day of rainfall. The observed runoff and peak discharge for the storm events are shown in Table 7.

\section{Conclusion}

Based on the use of a GIS environment, a GIS-USLE system that can provide quick and easy soil erosion estimations for many individual upland plots within the study area simultaneously was developed and applied using AVENUE script. The Mononobe, Triangle, and Trapezoidal techniques were used as the theoretical rainfall time distribution methods in order to estimate an erosivity factor, and the Mononobe method was judged to perform the best for GIS-USLE. However, more sophisticated and improved methods such as HUFF that can generate rainfall time distributions that are closer to those in a real storm event are needed in order to calculate a realistic erosivity factor for simulation and design purposes.

The soil erosions amounts from the 1,285 individual plots in the study area were estimated at an average of 5 tons/ha by 2 year return period with a $24 \mathrm{~h}$ maximum rainfall amount of 154.6 $\mathrm{mm}$, and the slope was found to be the most important factor affecting soil erosion estimates, as expected. The prototype was applied to the project area, and the results appeared to confirm this approach.

However, a critical problem, the sediment 
delivery ratio (SDR), was not considered in this study. Because the results from the USLE equation do not represent sediment yield but soil erosion, a consideration of SDR is required in order to compare the estimates from USLE with the observed erosion from an outlet of an individual field. Although SDR is taken into account in USLE factors such as the crop management factor by calibrating and reducing them as necessary in practice, more in-depth research is necessary in order to apply the USLE equation correctly.

\section{Acknowledgements}

This study was supported by the Technology Development Program for Agriculture and Forestry, Ministry of Agriculture and Forestry, Republic of Korea

\section{References}

1. Kim, U. T., Yoon, Y. N., Park, M. J., Yoo, C. S., 2001, A Study of Estimation of Sediment Yield Based on a Distributed System Concept, Journal of Korea Water Resources Association, 34(2): 131-140.

2. Youn, J. K., Won, Y. K., Yu, I. H., Lee, S. M., Min, K. D., 1994, GIS Technology for Soil Loss Analysis, The Journal of GIS Association of Korea, 2(2): 165-174.

3. Kim, J. T., Park, S. W., 1994, Runoff and Soil Losses from Sloping Lands with Different Cropping Practices, The Journal of Korea Society Agricultural and Biological Engineers, 36(1): 73-82.

4. Kim, C. W., Woo, H. S., Sonu, J. H., 1999, Estimation of Rainfall Erosivity in USLE, Journal of Korea Water Resources Asso- ciation, 32(4): 457-467.

5. Park, M. J., Kim, Y. S., 2001, The study of application for sediment yield model in the developing area, Journal of Korea Water Resources Association, 31(1): 3-17.

6. Son, K. I., 2001, Applicability examination of the RUSLE sediment yield prediction equations in Korea (I), Journal of Korea Water Resources Association, 34 (3): 199-207.

7. Woo, C. H., Hwang. K., 1996, A study on the value decision and the application method of USLE factors for the soil loss estimation in the large scale site development area using GIS - In the case of Buju mountain in Mokpo city, Jounal of Korea Institute of Landscape Architecture, 24(3): 115-132.

8. Woo, C. H., Hwang, K., 1998, Development of a GIS method for the automatic calculation of LS factor of USLE, Jounal of Korea Institute of Landscape Architecture, 26(3): 162-177.

9. Lee, N. J., Lee, Oh, S. J., Jung, P. K., 1996, Sol Loss and Water Runoff in a Watershed in Yeoju, Korean Journal of Soil Science and Fertilizer, 31(3): 211-215.

10. Cho, J. P., 1998, Applications of AGNPS model with rural watersheds having complex land use characteristics, M. S. thesis, Seoul National University.

11. Choi, J. K., Koo, J. W., Son, J. G., 1998, Review on the Unit Conversion with the USLE Application in Korea, Korean Journal of Soil Science and Fertilizer, 31(3): 301308 .

12. Korea Institute of Construction Technology, 1989, Analysis of Temporal Variations for Determining the Local Design Storms (Final).

13. Ouyang, D., Bartholic, J., 2001, Web-Based GIS Application for Soil Erosion Prediction, Proceeding of An International Symposium - 
Soil Erosion Research for the 21th Century.

14. Molnar, D. K., Julien, P. Y., 1998, Estimation of Upland Erosion using GIS, Conputer \& Geosciences, 24(2): 183-192.

15. Djokic \& Maidment, 2000, Hydrologic and Hydraulic Modeling Support with Geographic Information Systems.

16. ESRI, 1998, Programming with Avenue.

17. ESRI, 1999, Advanced ArcView GIS.

18. Foster G. R. et al., 1994, The Revised Universal Soil Loss Equation. Soil Erosion Research Methods

19. Yitayew, M., Pokrzywka, S. J., Renard, K. G., 1999, Using GIS for facilitating Erosion Estimation, American Society of Agricultural Engineers, 15(4): 295-301.

20. OnWordPress, 2000, ArcView GIS/Avenue
Programmer's Reference.

21. OnWordPress, 1999, ArcView GIS/Avenue Developer's Guide.

22. Kinnell, P. I. A., 2001, Slope length factor for applying the USLE-M to erosion in grid cells, Soil \& Tillage, 58: 11-17.

23. Wischmeier, W. H., 1976, Use and Miuse of the Universal Soil Loss Equation for Water-shed, Journal of Soil and Water Conservation, 31(1): 5-9.

24. Wischmeier, W. H., Smith, D. D., 1978, Predicting Rainfall Erosion Losses, USDA Agr. Handbook.

25. Wischmeier, W. H. et al., 1971, A Soil Erodibility Nomograph for Farmland and Construction sites, Journal of Soil and Water Conservation, 26: 189-193. 